\section{Perceived neighborhood characteristics and the functional performance of elderly people in the Belo Horizonte Metropolitan Area, Minas Gerais State, Brazil: a quantile regression analysis}

\section{Características percebidas da vizinhança e o desempenho funcional de pessoas idosas na Região Metropolitana de Belo Horizonte, Minas Gerais, Brasil: uma análise utilizando regressão quantílica}

Características percibidas del vecindario y el desempeño funcional de personas mayores en la Región Metropolitana de Belo Horizonte, Minas Gerais, Brasil: un análisis utilizando regresión cuantílica

\begin{abstract}
This study aims to examine the relationship between neighborhood characteristics and the functional performance of elderly people living in the Belo Horizonte metropolitan area, Minas Gerais State, Brazil. Data of a representative sample of 2,033 elderly were analyzed using quantile regression. Functional performance was measured by the number of activities of daily living $(A D L)$ the elderly had difficulty to perform. The neighborhood characteristics evaluated were: maintenance, trust, insecurity and defective sidewalks. Functional performance was found positively associated with the characteristic defective sidewalks, whose effect increased as the number of $A D L$ the elderly had difficulty to perform increased. The results suggest that inadequate sidewalk conditions can contribute to functional losses in elderly people, especially among those who are functionally more compromised.
\end{abstract}

Renzo Joel Flores Ortiz 1

Fabiane Ribeiro Ferreira 1,2

Maria Fernanda Lima-Costa 1,3

Cibele Comini César 1,4
1 Núcleo de Estudos em Saúde Pública e Envelhecimento, Fundação Oswaldo Cruzl Universidade Federal de

Minas Gerais, Belo Horizonte Brasil.

2 Departamento de

Fisioterapia, Universidade

Federal de Minas Gerais, Belo Horizonte, Brasil.

3 Departamento de Medicina

Preventiva e Social,

Universidade Federal de

Minas Gerais, Belo Horizonte, Brasil.

4 Departamento de

Estatística, Universidade

Federal de Minas Gerais, Belo Horizonte, Brasil.
Correspondence R. J. Flores Ortiz Núcleo de Estudos em Saúde Pública e Envelhecimento, Fundação Oswaldo Cruzl Universidade Federal de Minas Gerais.

Av. Augusto de Lima 1715 Belo Horizonte, $M G$ 30190-002, Brasil. renzojfo@gmail.com

Aged; Frail Elderly; Health of the Elderly 


\section{Introduction}

The characteristics of the environment within which people live, or neighborhood characteristics, can potentially influence a person's functional performance, especially the functional performance of elderly people, who have in the neighborhood the main, or even the only, diameter of living space 1,2. Defining functional performance as what a person does in the current or usual environment ${ }^{3}$, neighborhood characteristics may influence the functional performance of elderly people by facilitating or by hindering their engagement in activities and participation in daily life 1,3,4. For instance, while neighborhood characteristics like well-maintained sidewalks and the presence of public recreational facilities can encourage the elderly to engage in activities and participation 5,6, other neighborhood characteristics like poor public lighting and the lack of pedestrian crossings are more likely to lead the elderly to activity limitations and participation restrictions 7,8 , or disabilities, using the general term.

Limitations in activities and restrictions in participation induced by insecurity issues in the neighborhood may be attenuated with interventions such as an increase in police presence and the implementation of neighborhood watch programs 8,9 . Thus, disability is not necessarily a permanent condition, or related solely to the presence of morbidities. In certain cases, as exemplified, disability conditions may be overcome, either by creating environmental facilitators or by eliminating environmental barriers for expanded performance of actions and tasks in daily living 3 .

Several neighborhood characteristics have been identified as being associated with the functional performance of elderly people. These include aesthetics, safety, quality, accessibility, social cohesion, weather, noise, lighting, traffic, green spaces, handicap parking, healthcare services and uneven sidewalks 8,10,11,12,13,14,15,16,17,18. Although there is an important and growing body of literature providing evidence of the relationship between neighborhood characteristics and the functional performance of elderly people, in many studies key limitations regarding methodological issues are observed. For instance, functioning measures are commonly operationalized as binary and multinomial variables, a methodological approach which is likely to result in the loss of information ${ }^{19}$. Also, functioning studies commonly make use of regression analysis methods which allow the modeling of only the mean of the response variable, and hence are capable of providing a rather simplified description of the relationship between response and explana- tory variables. Because functional performance is a characteristic which can present certain heterogeneity among elderly people, the summarizing of a data analysis to a single position of the response distribution is a methodological approach which can also result in the loss of information 20 .

Introduced in 1978 by Roger Koenker and Gilbert Basset, quantile regression 21 is a regression analysis method that can be an alternative to mean-based regression methods. In fact, compared to a mean-based regression method like linear regression, quantile regression can be interpreted as an extension 22 . In common, both approaches deal with a continuous response variable that is linear in unknown parameters, but while linear regression models the mean of the response as a function of the explanatory variables, quantile regression models the percentiles of the response as a function of the explanatory variables 20 . Because any percentile can be modeled, quantile regression allows the examination of changes at any position of the response variable distribution, and also, because multiple percentiles can be modeled, it is still possible to examine changes in the distribution shape 20 . Therefore, compared to linear regression, which allows the examination of changes only at a central position of the response distribution, the mean, quantile regression can provide a broader description of the relationship between response and explanatory variables 22 . In the context of functioning studies, if we consider a response variable which consists of a population's levels of functioning, quantile regression allows one to examine the effects of the explanatory variables at distinct functioning levels. In contrast, meanbased regression methods would allow one to examine the effects of the explanatory variables only at the mean functioning level, and thus not exploring all available information of the functioning variable.

The present study aims to examine the relationship between neighborhood characteristics and the functional performance of the elderly who live in the Belo Horizonte metropolitan area, Minas Gerais State, Brazil. Unlike the majority of functioning studies which operationalize functioning measures as categorical variables and make use of mean-based regression analysis methods, we operationalize a functioning measure as a count variable and make use of a percentile-based regression analysis method, quantile regression. With this methodological approach we hope to perform a broader data analysis, which includes examining the effects of neighborhood characteristics at distinct functioning levels. 


\section{Methods}

\section{Source of data}

This study uses data from the Belo Horizonte Metropolitan Area Health Survey (Inquérito de Saúde da Região Metropolitana de Belo Horizonte, abbreviated as ISBH in Portuguese) undertaken in 2010 23. The ISBH is a health survey designed to provide a representative sample of the non-institutionalized adult population living in the Belo Horizonte metropolitan area. The survey sampling procedure consisted of a twostage cluster probabilistic sampling wherein in the first stage were selected census tracts and in the second stage were selected households of the selected tracts. All household residents aged 20 and older were invited to a face-to-face interview. Of the 7,500 households initially sampled, 5,798 participated in the survey and 12,979 residents were interviewed. Our study subjects were the residents aged 60 years and older who accounted for a sample of 2,271 individuals. According to Brazilian legislation, individuals aged 60 and older are classified as elderly 24 . The 2010 ISBH was approved by the Ethics Committee for Research with Human Beings of the René Rachou Research Center, Oswaldo Cruz Foundation (project protocol n. 10/2009). Further details may be found in Lima-Costa et al. 23.

\section{Study variables}

The response variable is the number of activities of daily living (ADL) performed with difficulty by the elderly, a measure of functional performance which was operationalized as a count variable. A total of $15 \mathrm{ADL}$ were evaluated, of which eight are considered basic ADL (getting out of bed, eating, combing one's hair or brushing one's teeth or washing one's face, walking from one room to another at the same level, bathing, dressing, toileting and cutting the nails of one's feet) and the remaining seven are classified as instrumental ADL (climbing ten steps, taking medication, walking two or three blocks, going out shopping, preparing one's own meal, taking a bus and undertaking household chores). These ADL have been validated and used in studies with elderly populations in Brazil 2,25,26,27.

The explanatory variables are organized into three groups: sociodemographic, health and neighborhood variables. The sociodemographic variables are: age, gender (female/male), occupational status (not working/working), place of residence (metropolitan Belo Horizonte/Belo Horizonte), education (illiterate/incomplete primary education/complete primary education or more) and role in the household (head/spouse/ other relations). The health variables are: regular use of medication (no/yes), use of healthcare services within the past 15 days (no/yes), number of comorbidities (none/ 1 to $3 /$ more than 3 ) and physical activity during leisure time (sedentary leisure/little activity-less than 3 times a week/ physically active-at least 3 times a week). Finally, the neighborhood variables, our main predictors, are: maintenance (fair/good), trust (no/yes), insecurity (no/yes) and defective sidewalks (no/ yes). The variables in this group were developed based on individual-level subjective measures (perceptions) as described below.

The measure of maintenance was based on the question "are you satisfied with the way the block where you live is cared for?" (no/yes). A "yes" answer was interpreted as an indicator of a neighborhood with good maintenance, while a "no" answer was interpreted as an indicator of a neighborhood with fair maintenance. The measure of trust was based on the question " $d o$ you think you can trust most people?" (no/ yes). A "yes" answer was interpreted as an indicator of trust. The measure of insecurity was based on the question "concern when leaving home: fear of being robbed?" (no/ yes). A “yes" answer was interpreted as an indicator of insecurity. Lastly, the measure of defective sidewalks was based on the question "concern when leaving home: fear of falling due to sidewalk defects?" (no/ yes). A "yes" answer was interpreted as an indicator of defective sidewalks.

\section{Data analysis}

We applied the quantile regression for count data approach 28 to estimate quantile regression models at every five percentiles in the 55th-95th percentile interval of the distribution of the number of ADL performed with difficulty. A total of nine quantile regression models were estimated with this procedure. Since $55 \%$ of the elderly had no difficulty in performing ADL, there is limited value in computing quantile regression models below the 55th percentile because all percentiles are zero and will not vary as a function of the explanatory variables. Each fitted model included the neighborhood, sociodemographic and health variables groups, where these last two groups include the variables that are considered potential confounders. From each fitted model the effects of the neighborhood variables and their standard errors were computed. These results are then presented graphically: the estimated effects and their 95\% confidence intervals (95\%CI) were plotted against the corresponding percentiles. In quantile regression models, the 
explanatory variables effects can be interpreted as rates of changes in the percentiles of the response variable distribution when the values of the explanatory variables vary 22 .

The quantile regression for count data approach 28 was applied using 5,000 simulated samples and the standard errors of the explanatory variables effects were computed using the delta method 29. Sample weights were included in the estimation process. Data analysis was carried out using R software version 3.1 (The R Foundation for Statistical Computing, Vienna, Austria; http://www.r-project.org).

\section{Results}

A total of 2,271 individuals aged 60 and older participated in the 2010 ISBH, of which 238 (approximately $11 \%$ ) presented missing data in at least one of the study variables and were excluded from the data analysis. The complete and missing data samples were similar with respect to age $(p=0.13)$, gender $(p=0.70)$ and occupational status ( $p=0.35$ ). Summary statistics of the study sample are presented in Table 1. On average the elderly had difficulty in performing 2.7 ADL and were 70 years old, the majority were female (60.9\%), did not work (82\%), resided in the capital, Belo Horizonte $(64.9 \%)$, did not have complete primary education (63\%) and were heads of households (70.2\%). Regarding health characteristics, most participants made regular use of medication (71\%), had not made use of healthcare services within the past 15 days (72.5\%), had one and up to three chronic health conditions (64.9\%) and reported sedentary leisure $(75.1 \%)$. Lastly, regarding neighborhood characteristics, were found the prevalences of $86.4 \%$ for good maintenance, $60.4 \%$ for trust, $58.4 \%$ for insecurity and $41.8 \%$ for defective sidewalks. The percentage of elderly with some difficulty in performing ADL, that is, the disability prevalence in the study sample, was $45 \%$ (Figure 1).

The percentiles of the number of ADL performed with difficulty stratified by categorical explanatory variables are presented in Table 2 . In this analysis we highlight the results for the variables occupational status, education and practice of physical activity: $95 \%$ of the elderly who worked had difficulty in performing less than four $\mathrm{ADL}, 95 \%$ of those who completed primary education or more had difficulty in performing less than nine ADL and 95\% who were physically active had difficulty in performing less than seven ADL.

Figure 2 presents the quantile regression estimated effects in the 55th-95th percentile in- terval of the distribution of the number of ADL performed with difficulty for the neighborhood characteristics. The shaded areas surrounding the effects estimates represent 95\%CI.

The effects of maintenance, trust and insecurity were not statistically significant in all the percentiles analyzed. To notice, the confidence intervals of the effects of these variables include the zero axis, or are very close, so that statistical significance is not clear to conclude. On the other hand, the effect of defective sidewalks was clearly statistically significant through the entire percentile interval, in addition to have varied. Precily, while for the elderly with difficulty in few ADL (55th percentile), defective sidewalks were associated with an increase of one ADL performed with difficulty, for the elderly with difficulty in many ADL (95th percentile), defective sidewalks were associated with an increase of six ADL.

\section{Discussion}

The prevalence of disability found in the study sample $(45 \%)$ is close to that found in Ferreira et al. 2 (47.1\%) and Costa e Silva et al. 30 (45.5\%), two other Brazilian studies that have also used basic and instrumental ADL to measure the functional status of elderly people. The procedure of combining basic and instrumental ADL items into one measure of functional status was based on the dimensionality of the ADL instrument used in the 2010 ISBH survey, which was found to have one dimension according to a recent study 31 . The dimensionality of an instrument reflects the number of constructs being measured 32 .

The comparison of disability/functioning indicators can be difficult because there are different ways of measuring functional status. For instance, in addition to the performance in ADL, functional status can be measured by evaluating mobility conditions through tasks such as transferring (changes in body positions), walking (short and long distances) and climbing stairs 33,34 . Furthermore, surveys have been used to assess more basic functions related to range of motion, strength and endurance, as well as the higher end of the functional spectrum, which includes walking medium and long distances and practicing vigorous exercise 33 . The comparison of disability indicators also requires attention because there are different definitions and theoretical models of disability. Following the World Health Organization's International Classification of Functioning, Disability and Health, in addition to limitations in activities, disability is defined also by restrictions in participation and impairments in body functions and structures, or more 
Table 1

Summary statistics of the study variables $(n=2,033)$. Belo Horizonte Metropolitan Area Health Survey, Minas Gerais State, Brazil, 2010

\begin{tabular}{|c|c|}
\hline Variable & n (\%) \\
\hline \multicolumn{2}{|l|}{ Response variable } \\
\hline Number of ADL performed with difficulty [mean (SD)] & $2.7(4.3)$ \\
\hline \multicolumn{2}{|l|}{ Sociodemographic characteristics } \\
\hline Age [mean (SD)] & $70.0(8.1)$ \\
\hline \multicolumn{2}{|l|}{ Gender } \\
\hline Female & $1,238(60.9)$ \\
\hline Male & $795(39.1)$ \\
\hline \multicolumn{2}{|l|}{ Occupational status } \\
\hline Not working & $1,667(82.0)$ \\
\hline Working & $366(18.0)$ \\
\hline \multicolumn{2}{|l|}{ Place of residence } \\
\hline Metropolitan Belo Horizonte & $714(35.1)$ \\
\hline Belo Horizonte & $1,319(64.9)$ \\
\hline \multicolumn{2}{|l|}{ Education } \\
\hline Illiterate & $197(9.7)$ \\
\hline Incomplete primary education & $1,281(63.0)$ \\
\hline Complete primary education or more & $555(27.3)$ \\
\hline \multicolumn{2}{|l|}{ Role in the household } \\
\hline Head & $1,427(70.2)$ \\
\hline Spouse & $407(20.0)$ \\
\hline Other relations & $199(9.8)$ \\
\hline \multicolumn{2}{|l|}{ Health characteristics } \\
\hline \multicolumn{2}{|l|}{ Regular use of medication } \\
\hline No & $590(29.0)$ \\
\hline Yes & $1,443(71.0)$ \\
\hline \multicolumn{2}{|l|}{ Use of healthcare services within the past 15 days } \\
\hline No & $1,474(72.5)$ \\
\hline Yes & $559(27.5)$ \\
\hline \multicolumn{2}{|l|}{ Number of comorbidities } \\
\hline None & $543(26.7)$ \\
\hline $1-3$ & $1,319(64.9)$ \\
\hline More than 3 & $171(8.4)$ \\
\hline \multicolumn{2}{|l|}{ Physical activity * during leisure time } \\
\hline Sedentary leisure & $1,526(75.1)$ \\
\hline Little activity (less than 3 times a week) & $178(8.8)$ \\
\hline Physically active (at least 3 times a week) & $329(16.2)$ \\
\hline \multicolumn{2}{|l|}{ Neighborhood characteristics } \\
\hline \multicolumn{2}{|l|}{ Perceived maintenance } \\
\hline Fair & $276(13.6)$ \\
\hline Good & $1,757(86.4)$ \\
\hline \multicolumn{2}{|l|}{ Perceived trust } \\
\hline No & $805(39.6)$ \\
\hline Yes & $1,228(60.4)$ \\
\hline \multicolumn{2}{|l|}{ Perceived insecurity } \\
\hline No & $846(41.6)$ \\
\hline Yes & $1,187(58.4)$ \\
\hline \multicolumn{2}{|l|}{ Perceived defective sidewalks } \\
\hline No & $1,183(58.2)$ \\
\hline Yes & $850(41.8)$ \\
\hline
\end{tabular}

ADL: activities of daily living; SD: standard deviation.

* Physical activity defined as any bodily movement produced by skeletal muscles that results in energy consumption. 


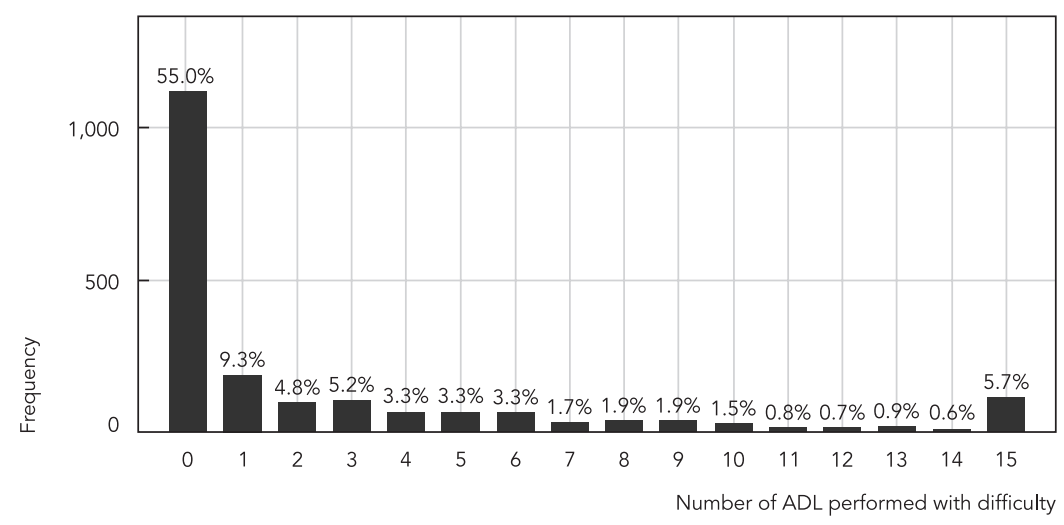

ADL: activities of daily living

precisely, by the interaction of these components in a context 3 .

The present study showed that the functional performance of the elderly who live in the Belo Horizonte metropolitan area was positively associated with defective sidewalks, and furthermore, that the effect of this neighborhood characteristic increased as the functional status of the elderly became more compromised. To our knowledge these results provide evidence which can be considered new: although sidewalk measures were already known to be associated with function related outcomes in older adults 15,18,35,36,37,38, no similar evidence was found with regard to the variation of the effect of sidewalk measures on function outcomes. As shown in Figure 1, while for the elderly with difficulty in few ADL (55th percentile), defective sidewalks were associated with an increase of one ADL performed with difficulty, for the elderly with difficulty in many ADL (95th percentile), defective sidewalks were associated with an increase of six ADL. Thus, a possible practical interpretation we can draw from this result is that inadequate sidewalk conditions may contribute to functional losses in elderly people, especially among the elderly who already have a more compromised functional status.

The information about the effects of neighborhood characteristics at distinct functioning levels can be important for policy planning pur- poses. For instance, knowing that the elderly who present more compromised functional status are at risk of a greater functional loss due to the influence of defective sidewalks, a policy maker may have more support to plan interventions better tailored to the needs of this specific group of the population. With respect to interventions in the urban environment to preserve or foment functioning, one can especially highlight those related to accessibility and safety ${ }^{39}$. In the city of Belo Horizonte, an example of accessibility-related intervention was implemented in 2010, when the municipality established that all sidewalks in the city should henceforth provide tactile guides and wheelchair ramps 40 .

Defective sidewalks or, more generally speaking, inadequate sidewalk conditions, may exert a particular influence on the performance of social related tasks like walking a few blocks and going out shopping, which are two of the seven instrumental ADL evaluated in this study. The findings of White et al. 18, for instance, support such a statement, since the authors found, in a sample of 436 elderly people, a statistically significant association between uneven sidewalks and limitations in social related tasks which included: visiting family and friends in their homes, going out with others to public places and taking part in organized social activities. The link between inadequate sidewalk conditions and limitations in 
Table 2

Percentiles of the number of activities of daily living performed with difficulty stratified by categorical explanatory variables. Belo Horizonte Metropolitan Area Health Survey, Minas Gerais State, Brazil, 2010.

\section{Variable}

Percentile

25th 30th 35th 40th 45th 50th 55th 60th 65th 70th 75th 80th 85th 90th 95th

Sociodemographic characteristics

Gender

Female

Male

Occupational status

Not working

Working

Place of residence

Metropolitan Belo Horizonte

Belo Horizonte

Education

Illiterate

Incomplete primary

Complete primary education or more

Role in the household

Head

Spouse

Other relations

Health characteristics

Regular use of medication

No

Yes

Use of healthcare services within the past 15 days

No

Yes

Number of comorbidities

None

$1-3$

More than 3

Physical activity

Sedentary leisure

Little activity (less than 3 times a week)

Physically active (at least 3 times a week)

Neighborhood characteristics

Perceived maintenance

Fair

Good

Perceived trust

No

Yes

Perceived insecurity

No

Yes

Perceived defective sidewalks

No

Yes

$\begin{array}{ccccccccccccccc}0 & 0 & 0 & 0 & 0 & 1 & 1 & 2 & 3 & 4 & 5 & 6 & 8 & 11 & 15 \\ 0 & 0 & 0 & 0 & 0 & 0 & 0 & 0 & 1 & 1 & 2 & 3 & 5 & 7 & 11 \\ 0 & 0 & 0 & 0 & 0 & 1 & 1 & 2 & 3 & 3 & 5 & 6 & 8 & 11 & 15 \\ 0 & 0 & 0 & 0 & 0 & 0 & 0 & 0 & 0 & 0 & 0 & 1 & 1 & 2 & 4 \\ 0 & 0 & 0 & 0 & 0 & 0 & 1 & 1 & 2 & 3 & 4 & 5 & 7 & 10 & 15 \\ 0 & 0 & 0 & 0 & 0 & 0 & 0 & 1 & 1 & 2 & 3 & 5 & 7 & 9 & 15 \\ 0 & 0 & 0 & 1 & 2 & 3 & 4 & 5 & 6 & 7 & 9 & 10 & 14 & 15 & 15 \\ 0 & 0 & 0 & 0 & 0 & 0 & 1 & 1 & 2 & 3 & 4 & 6 & 7 & 10 & 15 \\ 0 & 0 & 0 & 0 & 0 & 0 & 0 & 0 & 0 & 1 & 1 & 2 & 3 & 4.2 & 9 \\ 0 & 0 & 0 & 0 & 0 & 0 & 0 & 1 & 1 & 2 & 3 & 5 & 6 & 9 & 13 \\ 0 & 0 & 0 & 0 & 0 & 0 & 0 & 1 & 1 & 2 & 3 & 5 & 6 & 9 & 15 \\ 0 & 0 & 0 & 1 & 1 & 3 & 4 & 5 & 6 & 7 & 8 & 12 & 15 & 15 & 15\end{array}$

$\begin{array}{lllllllllllllll}0 & 0 & 0 & 0 & 0 & 0 & 0 & 0 & 0 & 1 & 1 & 2 & 3 & 5 & 10\end{array}$

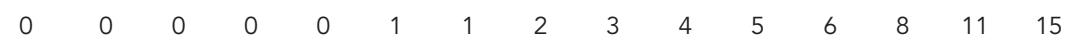

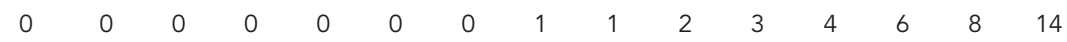

$\begin{array}{lllllllllllllll}0 & 0 & 0 & 0 & 0 & 1 & 2 & 3 & 4 & 5 & 6 & 8 & 9.7 & 13 & 15\end{array}$

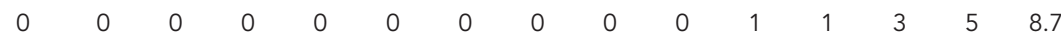

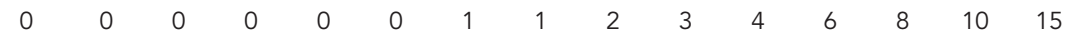

$\begin{array}{lllllllllllllll}0 & 1 & 2 & 3 & 3 & 4 & 4.8 & 6 & 6 & 8 & 9 & 10 & 11.3 & 15 & 15\end{array}$

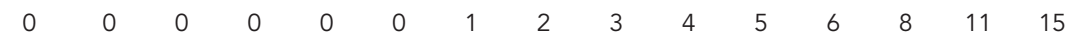

$\begin{array}{lllllllllllllll}0 & 0 & 0 & 0 & 0 & 0 & 0 & 0 & 1 & 1 & 2 & 3 & 4 & 5 & 8.2\end{array}$

$\begin{array}{lllllllllllllll}0 & 0 & 0 & 0 & 0 & 0 & 0 & 0 & 0 & 0.9 & 1 & 1.6 & 2.5 & 4 & 7.2\end{array}$

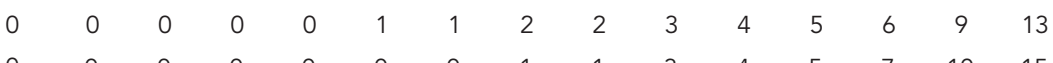

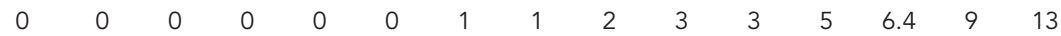

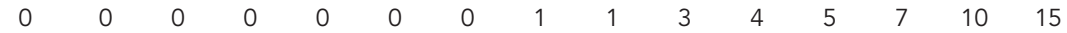

$\begin{array}{lllllllllllllll}0 & 0 & 0 & 0 & 0 & 0 & 0 & 0 & 1 & 1 & 3 & 4 & 6 & 8 & 13\end{array}$

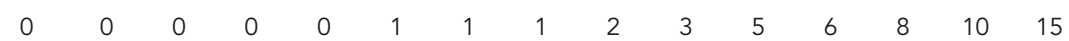

$\begin{array}{lllllllllllllll}0 & 0 & 0 & 0 & 0 & 0 & 0 & 0 & 0 & 0.1 & 1 & 2 & 3 & 5 & 9\end{array}$

$\begin{array}{lllllllllllllll}0 & 0 & 1 & 1 & 1 & 2 & 3 & 4 & 5 & 6 & 7 & 9 & 10 & 14 & 15\end{array}$ 
Quantile regression estimated effects in the 55th-95th percentile interval of the distribution of the number of ADL performed with difficulty for the neighborhood characteristics. Belo Horizonte Metropolitan Area Health Survey, Minas Gerais State, Brazil, 2010

2a) Maintenance (good compared to fair)

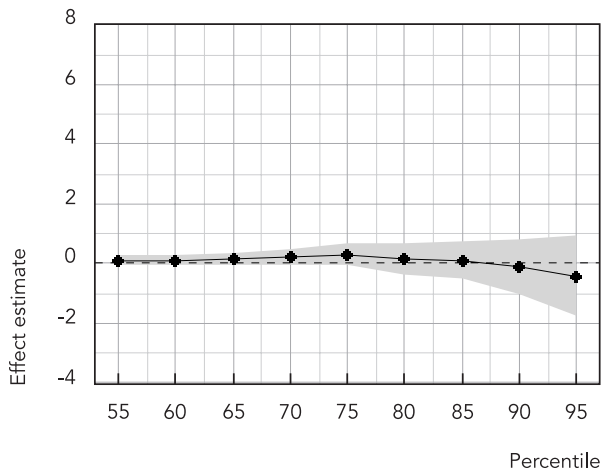

2c) Insecurity (yes compared to no)

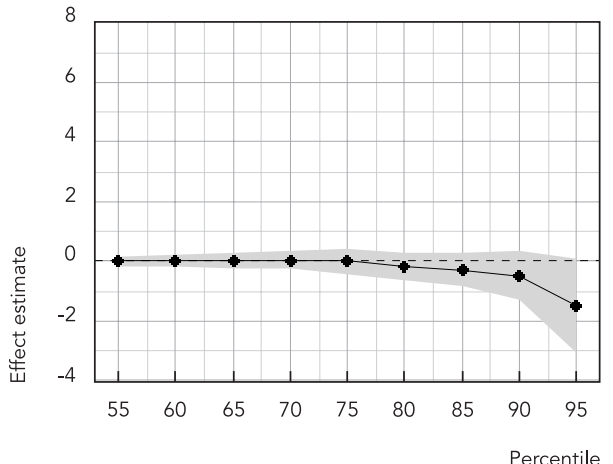

2b) Trust (yes compared to no)

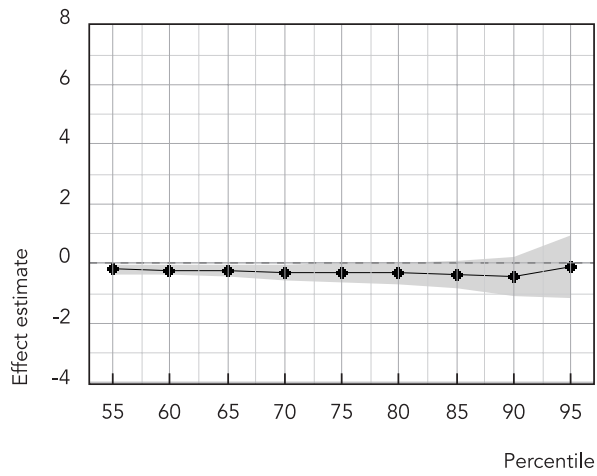

2d) Defective sidewalks (yes compared to no)

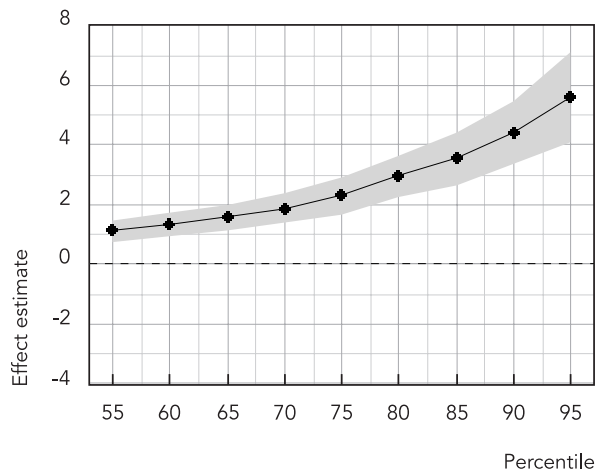

ADL: activities of daily living

social related tasks has also been found in qualitative studies. Strath et al. 35 , performing content analysis, identified that poorly maintained and missing sidewalks were among the neighborhood characteristics which most discouraged activity behavior in a sample of 37 older adults. Furthermore, the influence of inadequate sidewalk conditions is not only restricted to hindering the performance of social related tasks, but also to foster falls, fear of falling and fall-related injuries, which are important contributing factors for decreased mobility and increased functional dependence 41,42,43.

Although the quantile regression models do not appoint statistically significant associations between functional performance and the characteristics of maintenance, trust and insecurity, the descriptive analysis (Table 1) still provides results worth commenting on. For instance, since trust can be an important predictor of functioning 44 and of better health 45,46 , it is worrisome to find a high prevalence of a lack of trust (40.9\%). Also, the study sample shows a high prevalence of insecurity (59.5\%), another worrisome result since insecurity can be a neighborhood hurdle to elderly functioning 47,48 . However, it is important to highlight that there is evidence that the fear of crime, which can be interpreted as a proxy measure for neighborhood insecurity, can also strengthen trust among neighbors 49 . Furthermore, the des- 
criptive analysis shows a high prevalence of good maintenance $(85.2 \%)$, which is an important result since maintenance is a characteristic that is often associated with activity behavior 50,51 .

The description of the percentiles of the response variable stratified by categorical explanatory variables (Table 2) revealed that the elderly who work, have primary education level or higher, and are physically active have difficulty in performing few ADL. To some degree these results support previous evidence which showed that working, having some level of education and the practice of physical activity are protection factors for disability in older adults 2,52,53.

Two methodological issues can be considered as key strengths of our study: the operationalization of the functional performance measure and the data analysis method. To highlight the fact the broader data analysis achieved in this study was possible due to the combination of these two methodological approaches. While the operationalization of the functional performance measure as a count variable provided a wide range of functioning levels, quantile regression then allowed the analysis of distinct functioning levels.

Although quantile regression can provide important information not captured by usual mean-based regression methods it also has its disadvantages. These include increased computing time required for bootstrapping and other computational procedures and the fact that some aspects of the method are still being developed and have not yet been implemented in mainstream statistical software 54,55. However, software packages currently exist that are capable of performing quantile regression analyses, including SAS (SAS Inst., Cary, USA), Stata (StataCorp LP, College Station, USA), and R 55 .

\section{Contributors}

R. J. Flores Ortiz participated in the study's conceptualization, data analysis, interpretation of results, writing of the article and approval of the final version for publication. F. R. Ferreira and C. C. César contributed in the study's conceptualization, data analysis, interpretation of results, critical revision of the intellectual content and approval of the final version for publication. M. F. Lima-Costa collaborated in the critical revision of the intellectual content and approval of the final version for publication.
The limitations of our study should also be considered. First, although subjective neighborhood measures are closer to a person's perception, they make the study susceptible to same-source bias, a type of bias that occurs when a third unobserved factor, like psychological disposition, influences both a respondent's reporting on his/her neighborhood and on his/her health 56 .

Second, there are inherent limitations due to the use of secondary data. It should be noted that the data used were not collected to meet our specific research questions and, more importantly, that direct measures of neighborhood characteristics were not available. As a matter of fact, such measures were developed from measures of individual characteristics, which were used as proxy.

This study, therefore, calls attention to the different impacts that neighborhood characteristics may exert on the functional performance of elderly people, an evidence which, to our knowledge, still has not been presented in the literature. We also call attention to the practical contribution of our study, which is not only limited to addressing the fact that sidewalk conditions are important for elderly functioning. But furthermore, we have also addressed the issue of to whom sidewalk conditions can be more important. Based on our results we can say that sidewalk conditions are more important to the elderly who present more compromised functional status (95th percentile), since to these elderly the variable defective sidewalks was found associated with a greater functional loss. Thus, in conclusion, our study suggests that inadequate sidewalk conditions can contribute to functional losses in elderly people, especially among the elderly who already have a more compromised functional status.

\section{Acknowledgments}

R. J. Flores Ortiz received financial support from the Oswaldo Cruz Foundation. M. F. Lima-Costa and C. C. César received a research productivity grant from the Brazilian National Research Council (CNPq). 


\section{References}

1. Glass TA, Balfour JL. Neighborhoods, aging, and functional limitations. In: Kawachi I, Berkman LF editors. Neighborhoods and health. New York: Oxford University Press; 2003. p. 303-34.

2. Ferreira FR, César CC, Passos V, Lima-Costa MF Proietti FA. Aging and urbanization: the neighborhood perception and functional performance of elderly persons in Belo Horizonte Metropolitan Area - Brazil. J Urban Health 2010; 87:54-66.

3. World Health Organization. International classification of functioning, disability and health. Geneva: World Health Organization; 2001.

4. Verbrugge LM, Jette AM. The disablement process. Soc Sci Med 1994; 38:1-14.

5. Kwarteng JL, Schulz AJ, Mentz GB, Zenk SN, Opperman AA. Associations between observed neighborhood characteristics and physical activity: findings from a multiethnic urban community. J Public Health (Oxf) 2014; 36:358-67

6. Cerin E, Vandelanotte C, Leslie E, Merom D. Recreational facilities and leisure-time physical activity: an analysis of moderators and selfefficacy as a mediator. Health Psychol 2008; 27 (2 Suppl):S126-35.

7. Boclin KLS, Faerstein E, Leon ACMP. Neighborhood contextual characteristics and leisure-time physical activity: Pró-Saúde Study. Rev Saúde Pública 2014; 48:249-57.

8. Gallagher NA, Gretebeck KA, Robinson JC, Torres ER, Murphy SL, Martyn KK. Neighborhood factors relevant for walking in older, urban, African American adults. J Aging Phys Act 2010; 18:99-115.

9. Bennett GG, McNeill LH, Wolin KY, Duncan DT, Puleo E, Emmons KM. Safe to walk? Neighborhood safety and physical activity among public housing residents. PLoS Med 2007; 4:e306.

10. Clark CR, Kawachi I, Ryan L, Ertel K, Fay ME, Berkman LF. Perceived neighborhood safety and incident mobility disability among elders: the hazards of poverty. BMC Public Health 2009; 9:162.

11. Humpel N, Owen N, Leslie E. Environmental factors associated with adults' participation in physical activity: a review. Am J Prev Med 2002; 22:18899.

12. Luo Y. Perceived neighborhood environment and changes in health among older adults. In: Annual Meeting of the Population Association of America. http://paa2012.princeton.edu/papers/122672/ (accessed on 07/Aug/2014).

13. Strath SJ, Greenwald MJ, Isaacs R, Hart TL, Lenz EK, Dondzila CJ, et al. Measured and perceived environmental characteristics are related to accelerometer defined physical activity in older adults. Int J Behav Nutr Phys Act 2012; 9:40.

14. Balfour JL, Kaplan GA. Neighborhood environment and loss of physical function in older adults: evidence from the Alameda County Study. Am J Epidemiol 2002; 155:507-15.

15. Beard JR, Blaney S, Cerda M, Frye V, Lovasi GS, Ompad D, et al. Neighborhood characteristics and disability in older adults. J Gerontol B Psychol Sci Soc Sci 2009; 64:252-7.
16. Gong Y, Gallacher J, Palmer S, Fone D. Neighbourhood green space, physical function and participation in physical activities among elderly men: the Caerphilly Prospective study. Int J Behav Nutr Phys Act 2014; 11:40.

17. Sun F, Lu C. Influences of environmental factors on the physical functioning of older adults in urban China. J Sociol Soc Welf 2013; 40:29-49.

18. White DK, Jette AM, Felson DT, Lavalley MP, Lewis $\mathrm{CE}$, Torner JC, et al. Are features of the neighborhood environment associated with disability in older adults? Disabil Rehabil 2010; 32:639-45.

19. Slymen DJ, Ayala GX, Arredondo EM, Elder JP. A demonstration of modeling count data with application to physical activity. Epidemiol Perspect Innov 2006; 3:3.

20. Hao L, Naiman DQ. Quantile regression. Thousand Oaks: Sage Publications; 2007.

21. Koenker R, Bassett GW. Regression quantiles. Econometrica 1978; 46:33-50.

22. Davino C, Furno M, Vistocco D. Quantile regression: theory and applications. Chichester: John Wiley \& Sons; 2013. (Wiley Series in Probability and Statistics).

23. Lima-Costa MF, Turci M, Macinko J. A saúde dos adultos em Belo Horizonte. Belo Horizonte: Núcleo de Estudos em Saúde Pública e Envelhecimento, Fundação Oswaldo Cruz/Universidade Federal de Minas Gerais; 2012.

24. Presidência da República. Lei no 10,741 de 1o de outubro de 2033. Dispõe sobre o Estatuto do Idoso e dá outras providências. Diário Oficial da União 2003; 3 out.

25. Rosa TEC, Benício MHD, Latorre MRDO, Ramos LR. Determinant factors of functional status among the elderly. Rev Saúde Pública 2003; 37:408.

26. Alves LC, Leite IC, Machado CJ. The concept and measurement of functional disability in the elderly population: a literature review. Ciênc Saúde Coletiva 2008; 13:1199-207.

27. Ramos LR, Goihman S. Geographical stratification by socio-economic status: methodology from a household survey with elderly people in S. Paulo, Brazil. Rev Saúde Pública 1989; 23:478-92.

28. Machado JAF, Santos Silva JMC. Quantiles for counts. J Am Stat Assoc 2005; 100:1226-37.

29. Oehlert GW. A note on the delta method. Am Stat 1992; 46:27-29.

30. Costa e Silva MD, Guimarães HA, Trindade Filho EM, Andreoni S, Ramos LR. Fatores associados à perda funcional em idosos residentes no $\mathrm{Mu}$ nicípio de Maceió, Alagoas. Rev Saúde Pública 2011; 45:1137-44.

31. César CC, Mambrini JVM, Ferreira FR, Lima-Costa MF. Capacidade funcional de idosos: análise das questões de mobilidade, atividades básicas e instrumentais da vida diária via Teoria de Resposta ao Item. Cad Saúde Pública 2015; 31:931-45. 
32. Spector WD, Fleishman JA. Combining activities of daily living with instrumental activities of daily living to measure functional disability. J Gerontol B Psychol Sci Soc Sci 1998; 53:S46-57.

33. Guralnik JM, Fried LP, Salive ME. Disability as a public health outcome in the aging population. Annu Rev Public Health 1996; 17:25-46.

34. Peel C, Baker PS, Roth DL, Brown CJ, Bodner EV, Allman RM. Assessing mobility in older adults: the UAB Study of Aging Life-Space. Phys Ther 2005; 85:1008-119.

35. Strath S, Isaacs R, Greenwald MJ. Operationalizing environmental indicators for physical activity in older adults. J Aging Phys Act 2007; 15:412-24.

36. Giehl MWC, Schneider IJC, Corseuil HX, Benedetti TRB, d'Orsi E. Physical activity and environment perception among older adults: a population study in Florianópolis, Brazil. Rev Saúde Pública 2012; 46:516-25.

37. Christensen KM, Holt JM, Wilson JF. Effects of perceived neighborhood characteristics and use of community facilities on physical activity of adults with and without disabilities. Prev Chronic Dis 2010; 7:A105.

38. Keysor JJ, Jette AM, LaValley MP, Lewis CE, Torner JC, Nevitt MC, et al. Community environmental factors are associated with disability in older adults with functional limitations: the MOST study. J Gerontol A Biol Sci Med Sci 2010; 65:393-9.

39. Hughes SL, Leith KH, Marquez DX, Moni G, Nguyen HQ, Desai P, et al. Physical activity and older adults: expert consensus for a new research agenda. Gerontologist 2011; 51:822-32.

40. Prefeitura de Belo Horizonte. Decreto Municipal no 14.060 de 6 de agosto de 2010. Regulamenta A Lei no 8.616/03, que "Contém o Código de Posturas do Município de Belo Horizonte". Diário Oficial Municipal 2010; 7 ago.

41. Martin PE, Grabiner MD. Aging, exercise, and the predisposition to falling. J Appl Biomech 1999; 15:52-5.

42. Marks R. Physical activity and hip fracture disability: a review. J Aging Res 2011; 2011:741918.

43. Lockett D, Willis A, Edwards N. Through seniors' eyes: an exploratory qualitative study to identify environmental barriers to and facilitators of walking. Can J Nurs Res 2005; 37:48-65.

44. Mollenkopf H, Marcellini F, Ruoppila I, Flaschenträger P, Gagliardi C, Spazzafumo L. Outdoor mobility and social relationships of elderly people. Arch Gerontol Geriatr 1997; 24:295-310.
45. Bjornstrom EES. The neighborhood context of relative position, trust, and self-rated health. Soc Sci Med 2011; 73:42-9.

46. Satariano WA. Epidemiology of aging: an ecological approach. Burlington: Jones \& Bartlett Learning; 2006.

47. Piro FN, Nœss $\emptyset$, Claussen B. Physical activity among elderly people in a city population: the influence of neighbourhood level violence and self perceived safety. J Epidemiol Community Health 2006; 60:626-32.

48. King D. Neighborhood and individual factors in activity in older adults: results from the neighborhood and senior health study. J Aging Phys Act 2008; 16:144-70.

49. Oh JH, Kim S. Aging, neighborhood attachment and fear of crime: testing reciprocal effects. J Community Psychol 2009; 37:21-40.

50. Eichinger M, Titze S, Haditsch B, Dorner TE, Stronegger WJ. How are physical activity behaviors and cardiovascular risk factors associated with characteristics of the built and social residential environment? PLoS One 2015; 10:e126010.

51. Boehmer T, Hoehner CM, Wyrwich K, Brennan L, Brownson RC. Correspondence between perceived and observed measures of neighborhood environmental supports for physical activity. J Phys Act Health 2006; 3:22-36.

52. Costa Rosa TE, Benicio MH, Latorre MR, Ramos LR. Determinant factors of functional status among the elderly. Rev Saúde Pública 2003; 37:408.

53. Paterson DH, Warburton DER. Review physical activity and functional limitations in older adults: a systematic review related to Canada's Physical Activity Guidelines. J Int J Behav Nutr Phys Act 2010; 7:38.

54. Koenker R. Quantile regression. Cambridge: Cambridge University Press; 2005.

55. Olsen CS, Clark AE, Thomas AM, Cook LJ. Comparing least-squares and quantile regression approaches to analyzing median hospital charges. Acad Emerg Med 2012; 19:866-75.

56. Weden MM, Carpiano RM, Robert SA. Subjective and objective neighborhood characteristics and adult health. Soc Sci Med 2008; 66:1256-70. 


\section{Resumo}

Este estudo pretende examinar a relação entre características da vizinhança e o desempenho funcional de pessoas idosas que vivem na região metropolitana de Belo Horizonte, Estado de Minas Gerais, Brasil. Dados de uma amostra representativa de 2,033 idosos foram analisados utilizando regressão quantílica. O desempenho funcional foi medido pelo número de atividades da vida diária (AVD) que os idosos tiveram dificuldade para executar. As características da vizinhança avaliadas foram: manutenção, confiança, insegurança e passeios defeituosos. O desempenho funcional foi encontrado associado positivamente com a característica passeios defeituosos, cujo efeito aumentou à medida que o número de AVD que os idosos tiveram dificuldades para executar aumentou. Os resultados sugerem que condições inadequadas de passeios podem contribuir para perdas funcionais em pessoas idosas, especialmente entre aqueles que são funcionalmente mais comprometidos.

Idoso; Idoso Fragilizado; Saúde do Idoso

\section{Resumen}

Este estudio pretende examinar la relación entre las características del vecindario y el desempeño funcional de las personas mayores que viven en la región metropolitana de Belo Horizonte, Estado de Minas Gerais, Brasil. Datos de una muestra representativa de 2,033 personas mayores fueron analizados utilizando regresión cuantílica. El desempeño funcional se midió por el número de actividades de la vida diaria (AVD) que las personas mayores tuvieron dificultad para ejecutar. Las características del vecindario fueron: mantenimiento, confianza, inseguridad y aceras defectuosas. El desempeño funcional fue encontrado asociado positivamente con la característica aceras defectuosas, cuyo efecto aumentó a medida que el número de AVD que las personas mayores tuvieron dificultad para ejecutar aumentó. Los resultados sugieren que condiciones inadecuadas de aceras pueden contribuir para pérdidas funcionales en personas mayores, especialmente entre aquellos que son funcionalmente más comprometidos.

Anciano; Anciano Frágil; Salud del Anciano

Submitted on 11/May/2015

Final version resubmitted on 13/Nov/2015

Approved on 05/Jan/2016 